\title{
IMPLEMENTASI SWOT STRATEGI PEMASARAN ONLINEPADA COUNTER SUPER CELL DI KECAMATAN RIMBO BUJANG KABUPATEN TEBO
}

\author{
Delila Fitri Harahap, Wahit Hasim \\ Program Studi Manajemen Fakultas Ekonomi \\ Universitas Muara Bungo
}

\begin{abstract}
ABSTRAK
Penelitian ini bertujuan untuk mengetahui penjualan produk kepadakonsumen dan ingin lebih tahu banyak tentang produk apa yang ditawarkan.Dari dua strategi yang lebih baik dan lebih efektif untuk dilakukan sehinggaproduk dapat digunakan dan dibeli oleh masyaraka. Penelitian ini menggunakanmetode kualitatif dan analisis deskriptif yang menggunakan analisis SWOTMetode kualitatif seperti Metode Observasi, yaitu metode data denganpengamatan langsung ke counter Super Cell Kecamatan Rimbo BujangKabupaten Tebo dalam memasarkan produk. Dalam penelitian ini penulismengambil data pada Counter Super Cell .

Hasil dalam penelitian ini menunjukan bahwa pemasaran online counter Super Cell masuk pada tipe kuadran I. Posisi ini menandakan bahwa counter Super Cell berada di posisi yang kuat dan berpeluang, sehingga sangat memungkinkan untuk terus melakukan pemasaran secara online dan meraih kemajuan secara maksimal. Sedangkan pada analisis SWOT dengan membandingkan nilai IFAS dan EFAS menunjukan bahwa counter Super Cell berada pada situasi SO (strength, opportunities) dengan nilai 7,81 sehingga dapat disimpulkan bahwa strategi pemasaran secara online merupakan posisi yang sangat menguntungkan bagi counter Super Cell memiliki kekuatan dan peluang yang dapat digunakan secara maksimal dalam memasarkan produk secara online.
\end{abstract}

Kata Kunci: Implementasi SWOT Pemasaran Online Dan Offline

\section{Pendahuluan}

\begin{abstract}
Persaingan yang ada di berbagai bidang usaha, baik bidang usaha manufaktur maupun jasa, menuntut organisasi untuk dapat menciptakan keunggulan bersaing. Organisasi harus dapat menerapkan suatu strategi yang tepat agar persaingan organisasi dapat berhasil dengan baik, hal ini perlu agar dapat mengungguli organisasi pesaing, sehingga organisasi dapat tumbuh dan berkembang secara berkesinambungan. Organisasi harus dapat mengetahui kekuatan, kelemahan, peluang, dan ancaman yang dimiliki agar mengetahui, memahami, serta menerapkan suatu strategi yang baik. Analisis Strengths, Weaknesses, Opportunities, dan Threats
\end{abstract}

(SWOT) dilakukan secara internal dan eksternal organisasi. Analisis internal dilakukan untuk mengetahui kekuatan dan kelemahan organisasi, sedangkan analisis eksternal untuk mengetahui peluang yang dapat ditangkap, dan ancaman yang dihadapi organisasi. Analisis SWOT ini penting sebagai bagian organisasi untuk perumusan manajemen strategi yang akan dijalankan organisasi agar siap bersaing dan tidak dipandang sebelah mata oleh organisasi lainnya.

Wahyudi (2008) mengemukakan bahwa terdapat dua faktor yang menyebabkan suatu organisasi melakukan analisis terhadap lingkungan baik 
lingkungan internal maupun eksternal antara lain organisasi tidak berdiri sendiri tetapi berinteraksi dengan bagian-bagian dari lingkungannya yang selalu berubah setiap saat serta pengaruh lingkungan yang sangat rumit dan kompleks dapat mempengaruhi kinerja banyak bagian yang berbeda dari sebuah organisasi. Analisis SWOT mengidentifikasi kekuatan, kelemahan, peluang, dan ancamanyang dihadapi organisasi. Kekuatan dan kelemahan yang diidentifikasi oleh penilaian lingkungan internal, sedangkan peluang dan ancaman yang diidentifikasi oleh penilaian lingkungan eksternal (Dyson, 2007). Menganalisis lingkungan internal dan eksternal dengan menggunakan SWOT membantu untuk menentukan situasi saat ini dan untuk mengidentifikasi prospek utama dan tantangan yang signifikan. Jika digunakan dengan benar, SWOT dapat memberikan dasar yang baik untuk perumusan kebijakan.

Perkembangan dunia bisnis pada saat ini semakin pesat, hal ini dapat dilihat dari banyaknya pelaku bisnis yang baru. Perubahan yang cepat berdampak pada situasi ketidakpastian yang berpengaruh terhadap perusahaan. Di era modern ini, tingkat informasi sangat cepat beredar melalui jaringan komputer yang biasa disebut internet. Semakin majunya teknologi memberikan perubahan atau dampak pada gaya hidup belanja masyarakat yang bergeser dari transaksi offlinemenuju pada transaksi online.

Persaingan bisnis yang ketat seperti saat ini membuat pelaku bisnis selalu berusaha untuk mempertahankan usahanya dan bersaing untuk mencapai tujuan yang diharapkan. Banyak metode yang dilakukan pelaku bisnis agar usaha yang dijalankan tetap bertahan ditengahtengah persaingan yang ada, suatu usaha didirikan dan dikelola untuk menghasilkan suatu produk baik berupa barang maupun jasa. Dengan demikian diperlukan pemasaran yang baik karena, sebuah prinsip pemasaran mengatakan bahwa pencapaian tujuan organisasi tergantung pada seberapa mampu organisasi memahami kebutuhan dan keinginan pelanggan, dan memenuhinya secara lebih efisien dan efektif dibandingkan pesaingnya.

Setiap organisasi, baik bisnis maupun non bisnis tidak terlepas dari aktivitas pemasaran. Pemasaran merupakan aktivitas yang biasa dilakukan oleh setiap orang dalam hidupnya, memproduksi barang atau jasa untuk memuaskan kebutuhan dan keinginan pelanggan, menyampaikan produk ke konsumen merupakan contoh kegiatan pemasaran yang selalu dilakukan oleh organisasi atau lembaga. Pemasaran merupakan bagian yang penting dengan pasar, karena pasar yang ada sekarang merupakan pasar pembeli dimana terjadinya transaksi jual beli tergantung pada keputusan pembeli sendiri, sehingga pasar yang ada sangat dipengaruhi oleh perilaku para konsumen dan yang penting perusahaan sebagai yang menawarkan barang hanya bisa mengikuti kehendak konsumen dan bagaimana mengatasi persaingan-persaingan dari perusahaan yang menciptakan barang sejenis.

Dengan adanya internet, terdapat peluang yang sangat besar bagi perusahaanperusahaan sekarang ini untuk menggunakan bisnis online, karena bisnis onlinelebih praktis dan tidak memerlukan biaya yang besar, serta jangkauan pasar yang lebih luas karena melakukan pemasaran secara online. Alur transaksi pembayaran harus jelas sehingga tidak terjadi penyimpangan dalam proses transaksi penjualan.

Pada dasarnya pemasaran onlineadalah kegiatan komunikasi pemasaran dengan menggunakan media internet. Sesuai perkembangannya pemasaran onlinetidak hanya menggunakan media website, tapi juga $e$-maildan aplikasiaplikasi lain yang berjalan di atas protokol internet.Pemasaran online memiliki potensial untuk berkembang karena kebutuhan masyarakat akan informasi onlinesemakin tinggi dan penggunaan 
media internet dalam dunia pemasaran membawa perubahan baru dalam sisi pemasaran tradisional sehingga pemasaran Online dapat menjangkau masyarakat yang lebih luas dalam memperkenalkan produkmelalui internet pemasaran onlinejugatidak terbatas waktu karena internet tersedia untuk diakses setiap saat. Namun persaingan akan semakinsulit karena banyaknya usaha sejenis yang menggunakan strategi pemasaran online selain itu pemasaran online juga memiliki kelemahan dimana konsumen tidak dapat mencoba terlebih dahulu barang yang dia inginkan.

Seperti halnya pada CounterHandphone yang ada di pasar unit 2 Rimbo Bujang salah satunya adalah
CounterSuperCell, yang mana telah memasarkan produknya melalui internet. Strategi onlinedimulai pada tahun 2015 dimana pada saat itu penjualan onlinesedang trend.

Analisis seperti yang diuraikan di atas dapat dilakukan dengan menggunakan metode analisis SWOT, yaitu membandingkan peluang dan ancaman yang ditimbulkan dengan kekuatan dan kelemahan yang dimiliki oleh counter Super Cell. Hal ini penting untuk dilakukan dalam rangka menentukan strategi bersaing apa yang seharusnya dilakukan oleh counter Super Cell.Adapun tingkat penjualan online pada CounterSuperCell tahun 2019 sebagai berikut:

Tabel 1.1 Tingkat penjualan Online

Pada Counter Super Cell Tahun 2019

\begin{tabular}{|l|c|}
\hline \multirow{1}{*}{\multicolumn{1}{c|}{ Bulan }} & Penjualan \\
\cline { 2 - 2 } & Online \\
\hline Januari & 5Unit \\
\hline Februari & 8Unit \\
\hline Maret & 11 Unit \\
\hline April & 7Unit \\
\hline Mei & 13Unit \\
\hline Juni & 15Unit \\
\hline Juli & 12Unit \\
\hline Agustus & 9Unit \\
\hline September & 17Unit \\
\hline Oktober & 19Unit \\
\hline November & 4Unit \\
\hline Desember & 20Unit \\
\hline Jumlah & 140Unit \\
\hline
\end{tabular}

Sumber: Dokumen Counter Super Cell Tahun 2019

Tabel 1.1 diatas menunjukkan tingkat penjualan onlineyang dilakukan counter Super

Cellpada tahun 2019 sebanyak140 unit Handphone. dimana penjualan terbanyak terjadi pada bulan Desember sebanyak 20 unit, sedangkan penjualan terendah terjadi pada bulan januari dimana counter Super Cell hanya mampu menjual sebanyak 5 unit Handphone.

\section{Kajian pustaka}

Pemasaran merupakan proses kegiatan dari produsen ke tangan konsumen. Semua tujuan tersebut berhubungan dengan pasar di mana produsen yang membawakan barang akan bertemu dengan konsumen yang membutuhkannya. Disinilah letak kegiatan 
pemasaran dilakukan dan kegiatan pemasaran tersebut mencakup strategistrategi pemasaran perusahaan yang baik, cara-cara yang dilakukan perusahaan maupun saat kapan kegiatan tersebut dilakukan.

Ada beberapa definisi mengenai pemasaran diantaranya adalah : Menurut Kotler (Marketing) pemasaran adalah kegiatan manusia yang diarahkan untuk memenuhi kebutuhan dan keinginan melalui proses pertukaran.

Menurut Stanton pemasaran adalah keseluruhan intern yang berhubungan dengan kegiatan-kegiatan usaha yanag bertujuan untuk merencanakan, menetukan harga, mempromosikan dan mendistribusikan barang dan jasa yang akan mmuaskan kebutuhan pembeli baik pembeli yang maupun pembeli yang potensial.

Pemasaran Online atau EMarketing adalah sisi pemasaran dari ECommerce, yang merupakan kerja dari perusahaan untuk mengkomunikasikan sesuatu, mempromosikan, dan menjual barang dan jasa melalui internet (Armstrong dan Kottler, 2008). Menurut Chaffey, Pemasaran Online adalah penggunaan internet dan teknologi digital yang berhubungan untuk mencapai tujuan pemasaran dan mendukung konsep pemasaran modern. Kesimpulannya, Pemasaran Online adalah segala usaha yang dilakukan untuk melakukan pemasaran suatu produk atau jasa dengan menggunakan media internet.

Strategi pemasaran yang baik saat ini adalah sitem yang berbasiskan pada jaringan. Maksudnya sistem pemasaran ini bersifat online. Adapun manfaat dari pada sistem ini bisa dirasakan bagi kedua belah pihak yakni pihak penjual dan pembeli.

Pada dasarnya pemasaran online adalah kegiatan komunikasi pemasaran dengan menggunakan media internet. Sesuai perkembangannya pemasaran online tidak hanya menggunakan media website, tapi juga e-mail dan aplikasiaplikasi lain yang berjalan di atas protokol internet. Bagi para penjual, menerapkan sistem seperti ini berarti memangkas pengeluaran yang biasa dikeluarkan dalam sistem lama. Seperti, jika pada sistem lama kita harus membuka cabang baru demi melebarkan sayap bisnis kita, tidak dengan sistem online. Karena dengan sistem ini penjual dapat memperkenalkan hasil produknya melalui suatu web. Dimana setiap orang (konsumen) tidak hanya di satu lokasi bisa mengakses untuk mencari informasi akan barang yang diperlukan, tanpa perlu membuka cabang atau kantor pemasaran baru.

Bagi para konsumen, sistem ini sangatlah membantu. Karena konsumen tidak perlu datang langsung ke lokasi untuk membeli barang yang diinginkan, mengingat kondisi lalu-lintas kota yang cukup ramai yang menyebabkan terlalu banyak waktu yang kita buang dijalan untuk sampai ke lokasi. Maka dengan system online ini, konsumen bisa mendapatkan barang yang diinginkan cukup dari tempat duduknya.

Analisis SWOT Untuk Strategi Pemasaran Online

a. Strengths $(\mathrm{S})$

1. Online dapat menjangkau masyarakat yang lebih luas dalam memperkenalkan produk karena melalui internet

2. Online tidak terbatas waktu karena Internet tersedia untuk diakses setiap saat.

3. Untuk membangun hubungan dengan konsumennya.

4. Konsumen dapat langsung menemukan informasi yang tepat mengenai Handphone yang di jual

5. Biaya pemasaran di internet relatif sangat murah

b. Weaknesses $(\mathrm{W})$

1. Melalui media onlinekonsumen tidak dapat memesan melalui media internet, karena pada media internet hanya sebagai sarana 
mempromosikan dan pada media internet hanya mencantumkan contact person apabila ingin memesan.

2. Dalam strategi pemasaran onlinekonsumen tidak setiap orang mengetahui media internet

3. Pengikut pada media sosial masih sedikit, sehingga hanya sedikit yang bisa dijangkau

Bagi sebagian orang, biaya penggunaan internet mahal.

c. Opportunities $(\mathrm{O})$

1. Memiliki pasar yang potensial untuk bertumbuh

2. Kebutuhan masyarakat akan kebutuhan informasi onlineyang semakin tinggi.

3. Pola perilaku dan selera konsumen yang semakin berkembang dari informasi konvensional menjadi informasi online

4. Teknologi online yang terus berkembang

5. Penggunaan media internet dalam dunia pemasaran membawa perubahan baru dalam sisi pemasaran tradisional.

d. Threats $(\mathrm{T})$

1. Semakin banyak usaha sejenis yang menggunakan strategi pemasaran onlinekonsumen

2. Aplikasi onlinekemungkinan dapat dihack oleh hacker konsumen

3. Strategi pemasaran harus selalu uptode dalam memberikan informasi kepada konsumen.

\section{Metode Penelitian}

Metode Analisis Data Pada dasarnya merupakan proses penyederhanaan data agar lebih mudah dibaca dan diinterpresentasikan. Data yang ada akan dianalisis kedalam bentuk yang lebih sederhana untuk selanjutnya dicari makna dan implikasi yang lebih luas dari hasil penelitian (Wardiyanta dalam Samaji, 2015:38) Metode analisis yang digunakan dalam penelitian ini adalah metode analisis deskriptif dan analisis SWOT. Metode analisis deskriptif digunakan untuk analisa faktor pendorong dan penghambat pengembangan suatu Counter Super Cell. Sedangkan analisis SWOT digunakan untuk analisa strategi pengembangan Counter Super Cell

Analisis deskriptif merupakan salah satu metode pemecahan masalah dengan cara menggambarkan subjek atau objek penelitian saat ini dengan fakta yang tampak (Soejono dan Abdurrahman dalam Pradikta, 2013:37). Dalam penelitian ini, metode analisis deskriptif digunakan untuk memperoleh gambaran faktor pendorong dan panghambat pengembangan Counter Super Cell. Dengan menggunakan analisis deskriptif, maka data yang akan disajikan berupa data deskriptif berupa kata-kata tertulis dari perilaku yang diamati (Pradikta, 2013:37)

Teknik analisis data yang digunakan dalam penelitian ini adalah menggunakan teknik analisis SWOT dengan pendekatan kualitatif, yang terdiri dari Strenghts, Weakness, Opportunities dan Threaths. Analisis SWOT bertujuan untuk memaksimalkan kekuatan (strengths) dan peluang (opportunities), namun dapat meminimalkan kelemahan (weakness) dan ancaman (threaths). Menurut Rangkuti (2008), analisis SWOT adalah suatu identifikasi faktor strategis secara sistematis untuk merumuskan strategi. Strategi adalah alat yang sangat penting untuk mencapai tujuan (Porter. 2007). Sedangkan menurut Freddy Rangkuty (2008) strategi adalah perencanaan induk yang komprehensive yang menjelaskan bagaimana mencapai semua tujuan yang telah ditetapkan sebelumnya.

\section{Hasil Penelitin Dan Pembahasan}


Dari analisis SWOT di atas maka dapat disimpulkan bahwa masih adanya kelemahan dan ancaman bagi perusahaan dalam melakukan pemasaran secara online. Maka dari itu untuk mengetahui langkah-langkah apa saja yang perlu dilakukan counter Super Cell dalam menentukan kebijakan strategi pemasaran maka diperlukan analisis matriks SWOT yang bertujuan untuk mengetahui faktor kekuatan, kelemahan, peluang dan ancaman yang dimiliki counter Super Cell, sehingga dapat memberikan strategi pemasaran yang lebih baik. Berdasarkan matriks SWOT oleh Fred R. David maka diperoleh hasil analisis SWOT strategi pemasaran secara online yang dilakukan counter Super Cell, adalah sebagai berikut

Tabel 4.1Tabel IFAS

1. Kekuatan (strengtht)

\begin{tabular}{|c|l|r|r|r|}
\hline \multicolumn{2}{|c|}{ STRENGHT } & BOBOT & RATING & SKOR \\
\hline S1 & $\begin{array}{l}\text { Online dapat menjangkau masyarakat } \\
\text { yang lebih luas dalam memperkenalkan } \\
\text { produk karena melalui internet }\end{array}$ & 0,25 & 4 & 1 \\
\hline S2 & $\begin{array}{l}\text { Online tidak terbatas waktu karena } \\
\text { Internet tersedia untuk diakses setiap } \\
\text { saat }\end{array}$ & 0,25 & 3 & 0,75 \\
\hline S3 & $\begin{array}{l}\text { Konsumen dapat langsung menemukan } \\
\text { informasi yang tepat mengenai produk } \\
\text { yang ditawarkan }\end{array}$ & 0,25 & 4 & 1 \\
\hline S4 & $\begin{array}{l}\text { Biaya pemasaran di internet relatif } \\
\text { lebih murah }\end{array}$ & 0,25 & 5 & 1,25 \\
\hline \multicolumn{2}{|c|}{ Sub Total Kekuatan } & & & \\
\hline
\end{tabular}

2. Kelemahan (weakness)

\begin{tabular}{|c|l|r|r|c|}
\hline \multicolumn{2}{|c|}{ WEAKNESS } & BOBOT & RATING & SKOR \\
\hline S1 & $\begin{array}{l}\text { Tidak bisa membeli barang secara } \\
\text { langsung saat itu juga. }\end{array}$ & 0,428571 & 4 & 1,714286 \\
\hline S2 & $\begin{array}{l}\text { Pengikut pada media sosial masih } \\
\text { sedikit, sehingga hanya sedikit yang } \\
\text { bisa dijangkau }\end{array}$ & 0,142857 & 3 & 0,428571 \\
\hline S3 & $\begin{array}{l}\text { Bagi sebagian orang, biaya penggunaan } \\
\text { internet mahal }\end{array}$ & 0,285714 & 3 & 0,857143 \\
\hline S4 & $\begin{array}{l}\text { Kurangnya minat baca bagi masyarakat } \\
\text { terhadap iklan di media social }\end{array}$ & 0,142857 & 3 & 0,428571 \\
\hline \multicolumn{2}{|c|}{ Sub Total Kelemahan } & & 3,428571 \\
\hline
\end{tabular}


Tabel 4.2 Tabel EFAS

3. Peluang (opportunities)

\begin{tabular}{|c|l|r|r|r|}
\hline \multicolumn{2}{|c|}{ OPPORTUNITIES } & BOBOT & RATING & SKOR \\
\hline S1 & $\begin{array}{l}\text { Memiliki pasar yang potensial untuk } \\
\text { bertumbuh }\end{array}$ & 0,3125 & 4 & 1,25 \\
\hline S2 & $\begin{array}{l}\text { Kebutuhan masyarakat akan } \\
\text { kebutuhan informasi online yang } \\
\text { semakin tinggi }\end{array}$ & 0,25 & 3 & 0,75 \\
\hline S3 & $\begin{array}{l}\text { Pola perilaku dan selera konsumen } \\
\text { yang semakin berkembang dari } \\
\text { informasi konvensional menjadi } \\
\text { informasi online. }\end{array}$ & 0,1875 & 3 & 0,5625 \\
\hline S4 & $\begin{array}{l}\text { Teknologi online yang terus } \\
\text { berkembang }\end{array}$ & 0,25 & 5 & 1,25 \\
\hline \multicolumn{2}{|c|}{ Sub Total Peluang } & & 3,8125 \\
\hline
\end{tabular}

4. Ancaman (threats)

\begin{tabular}{|c|l|r|r|r|}
\hline \multicolumn{2}{|c|}{ THREATS } & BOBOT & RATING & SKOR \\
\hline S1 & $\begin{array}{l}\text { Semakin banyak usaha sejenis yang } \\
\text { menggunakan strategi pemasaran } \\
\text { online }\end{array}$ & 0,428571 & 2 & 0,857143 \\
\hline S2 & $\begin{array}{l}\text { Aplikasi online kemungkinan dapat } \\
\text { dihack oleh hacker }\end{array}$ & 0,142857 & 1 & 0,142857 \\
\hline S3 & $\begin{array}{l}\text { Strategi pemasaran harus selalu } \\
\text { update dalam memberikan informasi } \\
\text { kepada konsumen }\end{array}$ & 0,285714 & 2 & 0,571429 \\
\hline \multicolumn{2}{|c|}{ Sub Total Ancaman } & & & 1,57143 \\
\hline
\end{tabular}

\section{Kesimpulan}

Berdasarkan peneliti yang telah dilakukan oleh peneliti, maka ada beberapa kesimpulan yang dapat diambil dari penelitian ini, yaitu:

1. Perumusan strategi pemasaran counter Super Cell
Strategi pemasaran yang diterapkan oleh Counter Super Cell berdasarkan perumusan strategi pemasaran dapat diambil simpulan bahwa: pasar sasaran dari Counter Super Cell adalah menciptakan dan berusaha memberikan pelayanan yang sebaik baiknya sesuai dengan 
visi dan misi yang telah di terapkan di Counter Super Cel.

2. Hasil analisi SWOT menyebutkan bahwa counter Super Cell

Berada pada posisi kuadran 1 yang mana menunjukan bahwa counter Super Cell kuat dan berpeluang. Rekomendasi strategi yang diberikan adalah Agresif, artinya counter dalam kondisi prima dan mantap sehingga sangat dimungkinkan untuk terus melakukan ekpansi serta memperbesar pertumbuhan dan meraih kemajuan secara maksimal. Counter mempunyai peluang dan kekuatan sehingga dapat memanfaatkan peluang yang ada secara maksimal.

3. Langkah selanjutnya dalam pengambilan keputusan

Untuk strategi pemasaran pada counter Super Cell yang dapat dilakukan dengan strategi SO,WO,ST,WT yang memanfaatkan kekuatan dan peluang yang ada. Adapun strategi - strategi baru yang dihasilkan dalam pengembangan melalui Analisis SWOT pada counter Super Cell

a. Strategi SO (StrenghtOportunities) Yakni, untuk memperkuat pangsa pasar, peningkatan promosi pada media social, meningkatkan fasilitas dan pelayanan, meningkatkan promosi untuk produk baru, dan menggunakan mitra kerjasama.

b. Strategi

WO

(WeaknessOpportunities)

Yakni, untuk memperluas wilayah promosi, memaksimalkan peran manajemen strategis untuk pemasaran dan menjalin serta memperkuat krjasama. c. Strategi ST (StrenghtThreats)

Yakni, menetapkan strategi pemasaran, menampilkan keunggulan produk serta meningkatkan kepercayaan calon pembeli.

d. Strategi WT (WeaknessThreats) Yakni, untuk meningkatkan strategi pemasaran yang efektif dan efisien.

\section{SARAN}

Saran yang diberikan peneliti dalam penelitian ini khususnya bagi Counter Super Cell adalah

1. Dalam upaya meningkatkan pembeli maka promosi harus lebih gencar baik secara langsung maupun tidak langsung. Produk yang ditawarkan hendaknya memiliki keungulan yang tidak dimiliki oleh pesaing. Jaringan sangat berpengaruh terhadap kemajuan di dalam Counter Super Cell.

2. Di dalam strategi SO (strengthopportunities) tingkat kekuatannya sangat baik maka dari itu untuk dapat di pertahankan kemudian strategi ST(StrenghtThreats) tingkat kekuatannya cukup rendah maka dari itu untuk dapat meningkatkan strategi ST tersebut.

3. Di dalam strategi $\mathrm{WO}$ (WeaknessOpportunities)

tingkat kelemahan pada strategi ini cukup baik maka dari itu Strategi WO di pertahankan kemudian untuk strategi WT(WeaknessThreats) tingkat kelemahan pada strategi tersebut harus di tingkatkan agar bisa mncapai tingkat kekuatan. 